MACHINE BUILDING

МАШИНОБУДУВАННЯ

UDC 629.565.3

Yong Zhang ${ }^{1}, \mathrm{PhD}$,

I. Sydorenko ${ }^{2}$, DSc, Prof.,

I. Prokopovych ${ }^{2}$, DSc, Prof.,

Yunxuan Zhang',

S. Voronenko ${ }^{3}, \mathrm{PhD}$, Assos. Prof.

${ }_{1}^{1}$ Equipment Technology Department, Three Gorges Navigation Administration Bureau, No. 12, Shangdaodi Road, Xiling District, Yichang City, Hubei Province, China; e-mail: 407487591@qq.com

${ }^{2}$ Odessa Polytechnic State University, 1 Shevchenko Ave., Odessa, Ukraine, 65044; e-mail: sii@opu.ua

${ }^{3}$ Kherson State Marine Academi, 20 Ushakov Ave., Kherson, Ukraine, 73000; mail: vr.sergey@ukr.net

\title{
SIMULATION OF A FLOATING BOLLARD OF A SHIP LOCK BY THE FINITE ELEMENT METHOD
}

\begin{abstract}
Юн Чжан, І.І. Сидоренко, І.В. Прокопович, Юньсюань Чжан, С.В. Вороненко. Моделювання плавучого болларду суднового шлюзу методом кінцевих елементів. Одним з основних елементів швартового обладнання шлюзу $є$ плавучий боллард. Вихід з ладу даного елемента швартового обладнання завжди призводить до великих складнощів в організації судопропуска в шлюзі, в частині розміщення судів в камері шлюзу і вимушеного виводу шлюзів з роботи для приведення плавучих боллардів у робочий стан. Тому, аналіз працездатності даного елемента, як на стадії проектування, так і при експлуатації з урахуванням різних варіантів його навантаження при дії змінних зовнішніх умов, є актуальним завданням. У статті представлені результати дослідження однієї з конструкцій плавучого болларду суднового шлюзу, що знаходиться в реальній експлуатації. Дослідження проведені за допомогою методу скінченних елементів, при якому проведено 3D моделювання розглянутого пристрою і аналіз його напружено деформованого стану при різних варіантах навантаження, що враховують динаміку швартових операцій і погодні умови. Проведено порівняльний аналіз створеної скінчено-елементної моделі розглянутого пристрою з його спрощеною моделлю у вигляді пружної балкової системи з однорідним поперечним перерізом. Наведено графічну інтерпретацію результатів аналізу напружено деформованого стану розглянутого пристрою, при якому виявлені найбільш навантажені елементи конструкції. Виявлену локацію місць найбільш масштабного напружено деформованого стану запропоновано застосувати як теоретичну основу для розгортання датчиків системи попередження про стан навантаження плаваючого болларду суднового шлюзу. елементу

Ключові слова: річковий шлюз, плаваючий боллард, 3D моделювання, напружено-деформований стан, метод кінцевого

Yong Zhang, I. Sydorenko, I. Prokopovych, Yunxuan Zhang, S. Voronenko. Simulation of a floating bollard of a ship lock by the finite element method. One of the main elements of the lock's mooring equipment is the floating bollard. Failure of this element of the mooring equipment always leads to great difficulties in organizing ship passes in the lock, in terms of the arrangement of vessels in the lock chamber and the forced withdrawal of locks from work to bring the floating bollards into working condition. Therefore, the analysis of the performance of this element, both at the design stage and during operation, taking into account various options for its loading under the action of changing external conditions, is an urgent task. The article presents the results of a study of one of the structures of a floating bollard of a ship's lock, which is in real operation. The studies were carried out using the finite element method, in which 3D modeling of the device under consideration was carried out and its stress-strain state was analyzed under various loading options, taking into account the dynamics of mooring operations and weather conditions. A comparative analysis of the created finite element model of the device under consideration with its simplified model in the form of an elastic beam system with a uniform cross section is carried out. A graphic interpretation of the results of the analysis of the stress-strain state of the device under consideration is given, in which the most loaded structural elements are distinguished. The identified location of the places of the largest stress-strain state is proposed to be used as a theoretical basis for the deployment of sensors of the system for alerting the state of the loading of the floating bollard of the ship lock.

Keywords: river lock, floating bollard, 3D modeling, stress-strain state, finite element method
\end{abstract}

\section{Introduction}

A modern shipping lock is a highly mechanized hydraulic structure with automatic control of the process of locking ships. However, to this day, there are several problems in this automated chain of passages associated with the mooring of the vessel in the chamber. One of these problems is as fol-

\section{DOI: 10.15276/opu.1.63.2021.01}

(c) 2021 The Authors. This is an open access article under the CC BY license (http://creativecommons.org/licenses/by/4.0/). 
lows. Hard and heavy mooring ropes are used during mooring of large-tonnage vessels. It is practically impossible to moor a ship with such ropes "tight". The presence of sagging ropes and their pulling lead to significant movements of vessels along the lock chamber, which causes inertial jerks. The kinetic energy of jerks, not absorbed by the mooring ties, leads to the breakage of the mooring ropes, the destruction of both the hooks of the floating bollards (floating eyelets) and the floating bollards or ship bollards themselves.

The very locking of heavy-duty vessels during the design mode of filling (emptying) the lock chamber often causes a significant excess of the permissible standard hydrodynamic force, which can create an emergency situation causing the destruction of these elements. In this regard, the analysis of existing structures of floating bollards and new designed structures under the influence of external loads is a prerequisite that determines their efficiency and reliability.

\section{Analysis of literary data and problem statement}

One of the main elements of the lock's mooring equipment is a floating bollard (Fig. 1, a). It consists of a float 1 , structurally identical to the lower (under water) and upper 2 carriages [1]. The upper bogie has an eye (hook) 3 for attaching a mooring cable. The structure moves along the guide 4 of the airlock. Failure of this element of mooring equipment always leads to great difficulties in organizing the passage of ships into the lock, from the point of view of placing ships in the lock chamber and stopping the lock for operations to bring floating bollards into working condition $[2,3]$.

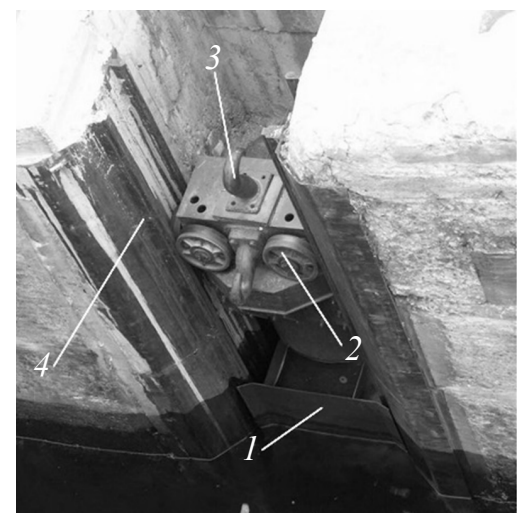

$a$

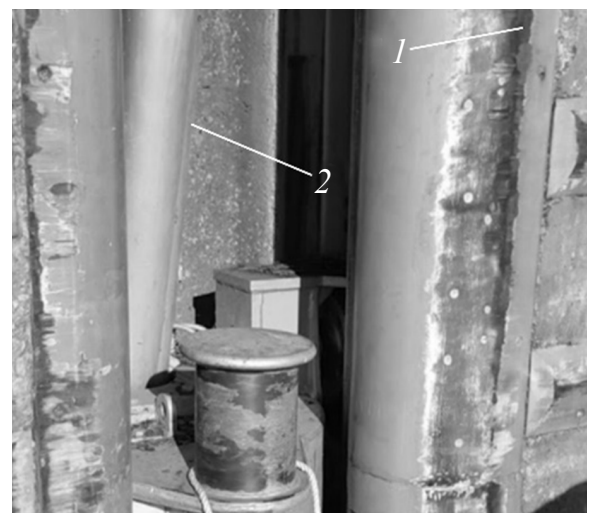

$b$

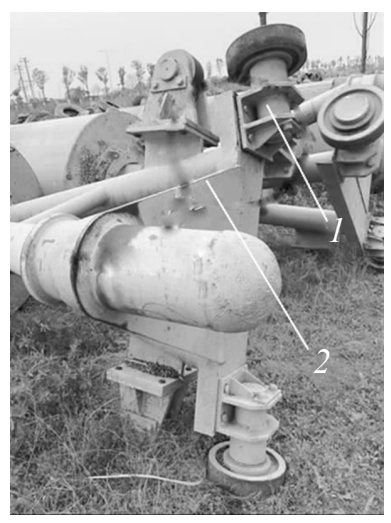

C

Fig. 1. Floating bollard: general view of the bollard $(a)$ destruction of concrete and guides in the bollard shaft $(b)$ destruction of the bollard structure $(c)$

There are two main reasons for the failure of floating bollards, differing in the place of origin $[4,5]$. One of the reasons is the destruction of the entire system of floating bollards, recorded in $20 \%$ of cases [6,7]. Such destruction manifests itself in the form of destruction of concrete at the points of attachment of the guides 1 and destruction or critical plastic deformation of the guide rollers of the carriages of the bollards 2, which leads to its jamming in the mine (Fig. 1,b). However, they indicate that these damages are the result of another reason, namely, the destruction of the bollard structure itself, namely, the metal structures of the frame 1 and the attachment points of the rollers 2 (Fig. 1,c). Such destruction of the floating bollard is $80 \%$ of the recorded cases $[8,9]$.

Based on the foregoing, it should be recognized that the main element that determines the performance of the presented sluice device is the floating bollard itself [10]. Therefore, one of the priority tasks, the solution of which makes it possible to judge the operability of this device, is its mathematical modeling both at the stage of its design and at the stage of operation of the finished device, taking into account various options for external influences.

The analysis of the existing structures of floating bollards made it possible to establish that they are welded bar, plate or shell structures [11]. However, most often the bollard design is mixed; rods, plates and shells can be present in it simultaneously $[12,13]$. 
One of the effective methods for modeling and studying the stress-strain state of mechanical structures is the finite element method (FEM) $[14,15,16]$.

When using FEM the solution of any engineering problem begins with the preparation of a computational model in the form of a virtual analogue of a real building structure as well as technological product and mechanism detail, etc. From a geometric point of view, a computational model is a field of points connected by primitives (straight line segments, triangles, rectangles, etc.). This is how a kind of mesh structure is formed - the geometry of the original structure is approximated by the mesh superimposed on it, and further work is carried out not with the original system, but with the resulting mesh. In addition to geometry, the primitives connecting the model nodes also have known mechanical properties. This means that by linking the stiffnesses of all mesh elements into a single whole (within the framework of the assumptions made in the model), it is possible to establish the stressstrain state of the entire system. So, using this method, you can get any factors of interest: longitudinal and transverse forces, bending and torsional moments, stresses, deformations, etc. Considering that this method is currently implemented in many CAE systems such as ABAQUS, ANSYS, NASTRAN, Siemens NX, LS Dyna, which in turn are inextricably linked with CAD systems - the use of the FEM method is the most preferable.

\section{Purpose and tasks of the research}

The aim of the study is to model and analyze the stress-strain state of the superstructure of a vertical floating bollard used in the ship lock \#1 of Gechzhouba (China).

The objective of the study is to identify the most loaded structural elements that determine the operability of the device under consideration, with a variation in the magnitude of external influences acting on it. The magnitudes of the considered impacts are presented in Table 1.

Table 1

Values of the considered external influences on the floating bollard

\begin{tabular}{|c|c|c|c|}
\hline $\begin{array}{c}\# \\
\text { option }\end{array}$ & General terms & Special condition & $\begin{array}{l}\text { External influence } \\
\text { on the eyelet of a } \\
\text { bollard }\end{array}$ \\
\hline 1 & \multirow{3}{*}{$\begin{array}{c}\text { Force } \\
\text { the gravity of } \\
\text { the device } \\
G=8.1554 \mathrm{kN} \\
\text { is compensated } \\
\text { by the buoyan- } \\
\text { cy of the water, } \\
\text { determining } \\
\text { zero buoyancy }\end{array}$} & Estimated pulling force of the ship's lock when filling it & $F=150 \mathrm{kN}$ \\
\hline 2 & & $\begin{array}{l}\text { Estimated pulling force of the ship's lock during its filling } \\
\text { and dynamic loads associated with jerks due to the pres- } \\
\text { ence of sagging and stretching of the ropes }\end{array}$ & $F=200 \mathrm{kN}$ \\
\hline 3 & & $\begin{array}{l}\text { The calculated tractive effort of the ship's lock during its } \\
\text { filling, dynamic loads associated with jerks due to the } \\
\text { presence of sagging of the ropes and their stretching, as } \\
\text { well as loads associated with an increase in the mass of the } \\
\text { ship in winter conditions due to its freezing }\end{array}$ & $F=300 \mathrm{kN}$ \\
\hline
\end{tabular}

It should be noted, that the special loading conditions in the winter period are of the greatest interest, since it was during this period that the largest number of damages to floating bollards was recorded.

\section{Materials and methods of research}

The upper part of the floating bollard was modeled as the most loaded and determining the operability of the entire device (Fig. 2,a). In the simulation, the element of the upper part of the floating bollard was considered as a hollow thin-walled cylinder with an outer diameter of $160 \mathrm{~mm}$, an inner diameter of $110 \mathrm{~mm}$, and a height of $1200 \mathrm{~mm}$ (Fig. 2, b).

Since there is no specific size and shape of the lid located on the top of the bollard, the use of a round lid with a thickness of $25 \mathrm{~mm}$ is considered. The mooring force is applied at point $\mathbf{A}$ of the bollard eyelet. In 3D modeling by means of Autodesk Inventor, vertical 1 and horizontal 2 rollers of the upper structure of a floating bollard, for simplicity, were geometrically generalized into eight threedimensional prisms (Fig. 2,c). 


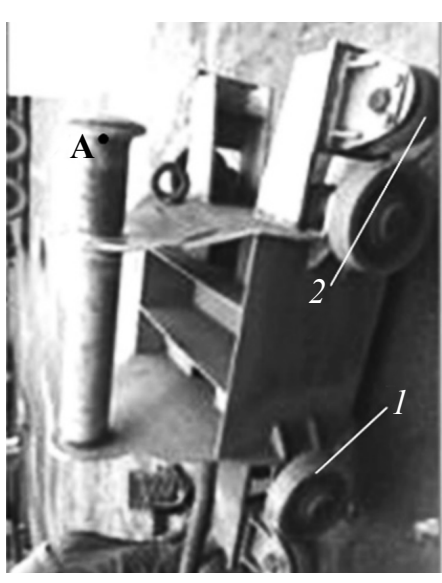

$a$

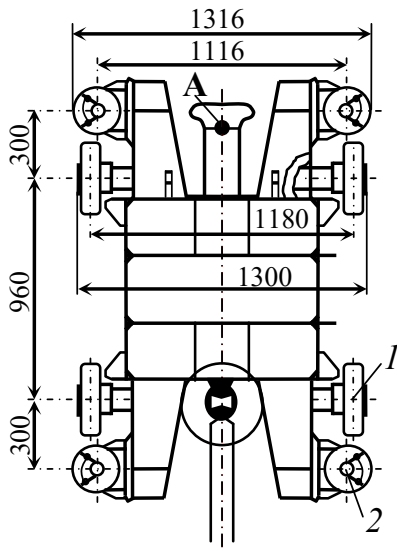

$b$

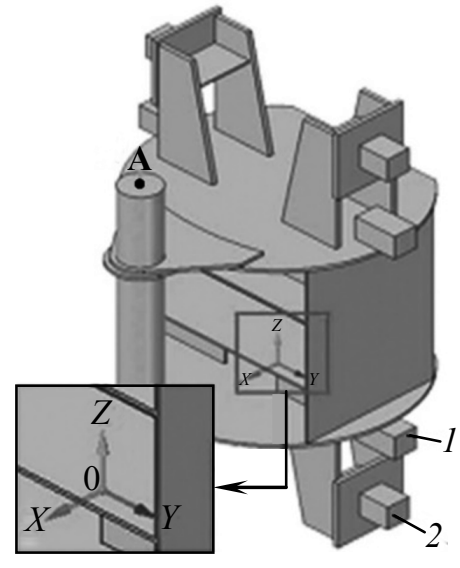

$c$

Fig. 2. Floating bollard in ship lock \#1 of Gezhouba (China): exterior (a); overall dimensions (b); 3D model (c)

When modeling the upper part of a floating bollard, the use of materials of three types is considered. Flat plates of the bollard structure, parallel to the $X 0 Y$ plane, are made of stainless steel 08X18H10T GOST 5582-75 (1Cr18Ni9Ti - China), the body of the hollow cylinder system is made of Steel 45 GOST 1577-93 (ZG310-570 - China), and the rest of the parts are made of steel St3ps according to GOST 380: 2005 (Q235B - China). The corresponding characteristics of the materials used are shown in Table 2.

Table 2

Characteristics of the materials used in the manufacture of the upper part of the floating bollard

\begin{tabular}{c|c|c|c|c|c}
\hline Material & $\begin{array}{c}\text { Elastic modulus } \\
\mathrm{E}, \mathrm{GPa}\end{array}$ & Poisson's ratio $\mu$ & $\begin{array}{c}\text { Density } \\
\rho, \mathrm{kg} \cdot \mathrm{m}^{-3}\end{array}$ & $\begin{array}{c}\text { Yield point } \\
{\left[\sigma_{\mathrm{T}}\right], \mathrm{MPa}}\end{array}$ & $\begin{array}{c}\text { Tensile strength } \\
\text { tensile }\left[\sigma_{\mathrm{p}}\right], \mathrm{MPa}\end{array}$ \\
\hline $\begin{array}{c}\text { St3ps (CT3חc) } \\
\text { GOST 380-2005 } \\
(\mathrm{Q} 235 \mathrm{~B})\end{array}$ & 200 & 0.3 & 7.850 & 250 & 460 \\
\hline $\begin{array}{c}\text { Steel 45 } \\
\text { GOST 1577-93 } \\
(\text { ZG310-570) }\end{array}$ & 200 & 0.3 & 7.850 & 310 & 570 \\
\hline $\begin{array}{c}\text { 08X18H10T } \\
\text { GOST 5582-75 } \\
(1 \mathrm{Cr} 18 \mathrm{Ni9Ti})\end{array}$ & 193 & 0.31 & 7.750 & 207 & 586 \\
\hline
\end{tabular}

To analyze the presented product, the CAE system ANSYS Workbench was used. The discrete method implemented in the Solid186 (3D20N) block was used to create a 3D mesh of the upper part of the floating bollard. The unit cell of the grid is a parallelepiped (cube) with a side length of $20 \mathrm{~mm}$. Several surface constraints have been applied to the surfaces of the prisms corresponding to the eight horizontal and longitudinal rollers. Constraints for the nodes of each finite element on the surface of the corresponding prism in the direction of 6 degrees of freedom determined its complete immobility (displacements and angles of rotation are equal to 0 ).

To check the correctness of mathematical modeling and analysis of the structure using the FEM, its simplified calculation was carried out under the action of the working force according to option 1 (see Table 1). When simplifying the model of the upper part of a floating bollard, its real structure is presented as an elastic beam system with a uniform cross-section (Fig. 3, a). The stainless steel plates used to fix the bollard are presented as two hinged supports of the beam, limiting the movement along the $0 X$ axis (Fig. 3, $b$ ). The displacement of the beam in two directions relative to the $0 Z$ axis determines the possibility of its rotation about the $0 Y$ axis. 


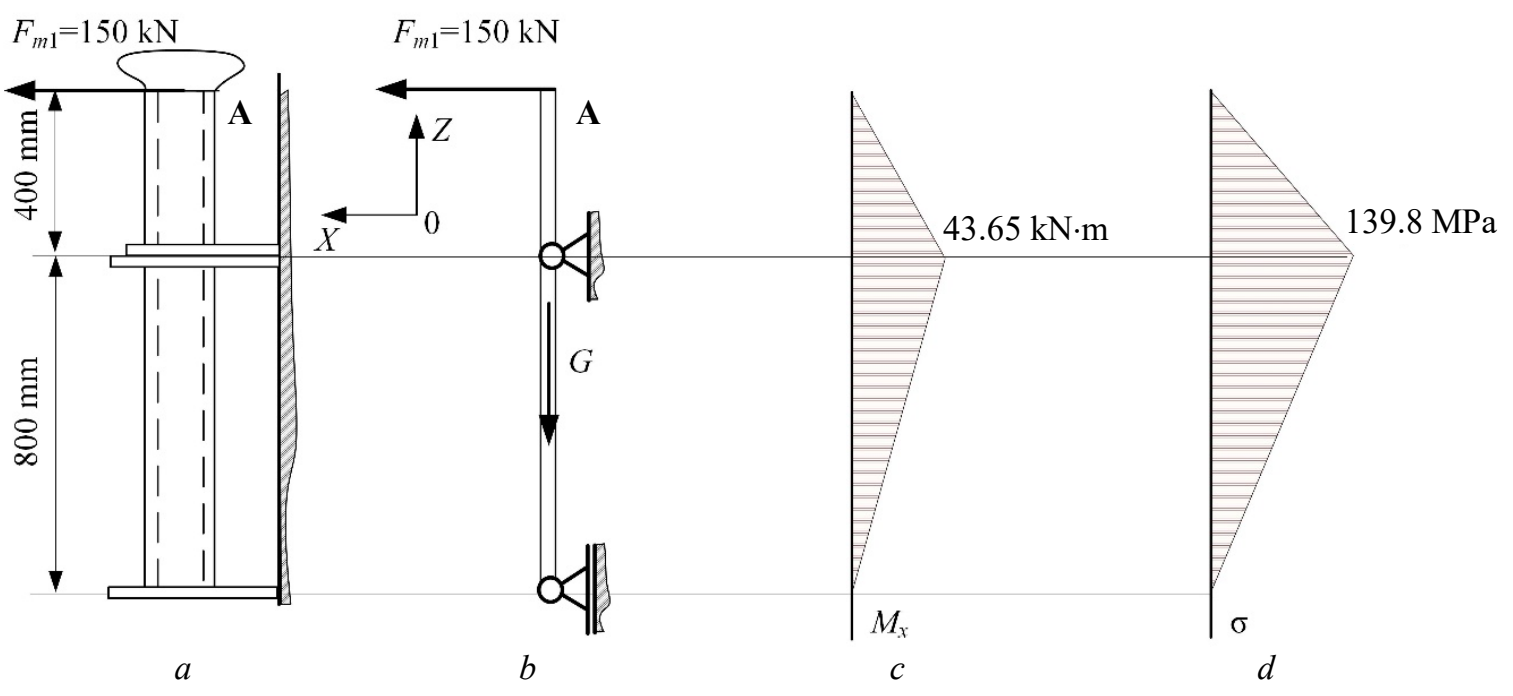

Fig. 3. Simplified model for calculating loads and stresses in the considered column with loading case 1: geometric parameters $(a)$; calculation scheme $(b)$; bending moments $(c)$; bending stress $(d)$

For a simplified design model, the distribution of the bending moment of the beam along its main axis was obtained (Fig. 3,c). which made it possible to obtain the distribution of the corresponding stresses (Fig. 3, d). These calculations were carried out in accordance with the existing regulatory documents [13]. They indicate that tensile and bending stresses of elements of metal structures can be calculated using the following relationship:

$$
\sigma=\frac{M_{x}}{\gamma_{x} W_{n x}}
$$

where $M_{x}$ is the calculated value of the maximum bending moment acting along the main axis; $\gamma_{x}$ is the coefficient of plasticity of the module section; $W_{n x}$ - module of net section along the $x$-axis.

Since the simplified model of the beam is bent only in one main plane, when carrying out the calculation, it was taken for a uniform design section $W_{n x}=3.126 \cdot 10^{-4} \mathrm{~m}^{3}$, the corresponding coefficient of plasticity of the section of the modulus $\gamma_{x}=1.0$.

Subsequent calculations by the FEM method made it possible to obtain diagrams of stress clouds in the structure of the upper part of a floating bollard (Fig. 4).

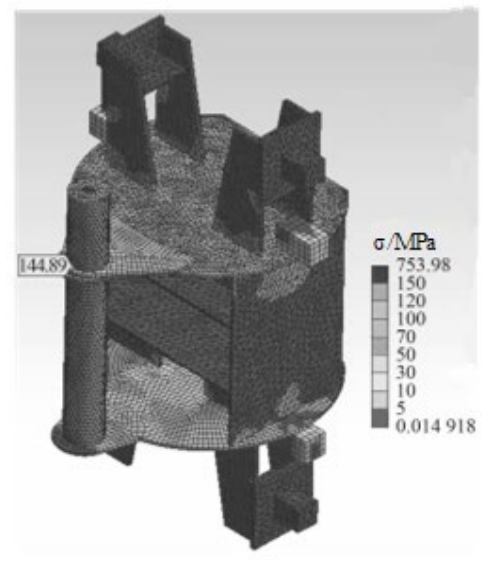

$a$

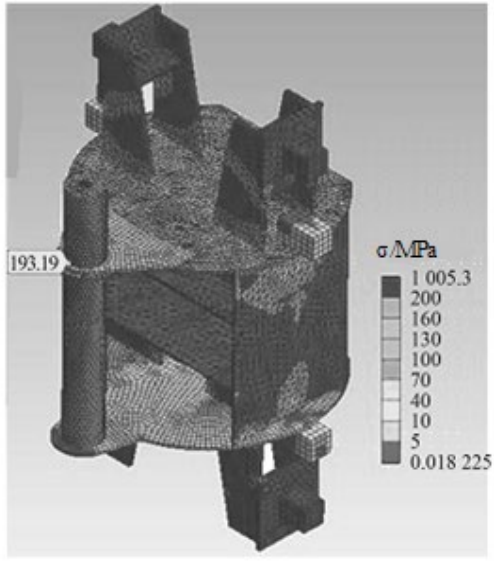

$b$

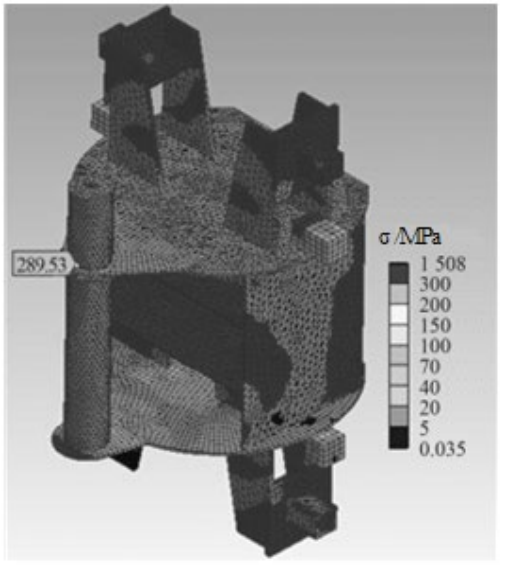

c

Fig. 4. Stresses in the model when calculating by the finite element method: design load according to option $1(a)$; design load for option $2(b)$; design load for variant 3 (c) 
Stress cloud diagrams show that the stress on the body of the hollow cylindrical column and stainless steel plates parallel to the $X 0 Y$ plane is greater than in other parts of the structure, especially in those places where these plates are close to each other. It should be noted that the stress distribution is more pronounced in the protruding part of the bollard.

Comparison of the results of calculating stresses for the finite element model $(144.9 \mathrm{MPa})$ and the simplified design model (139.8 MPa) in the case of loading case 1 (see Table 1) in the same place shows that they are very close, and the relative error between them is about $3.6 \%$ (see Fig. 3, $d$ and Fig. 4, $a$ ).

Such a small error indicates the correct modeling of the node under consideration when calculating it by the FEM method. With this variant of the calculation, it was found that the value of the stress of the numerical simulation is $144.9 \mathrm{MPa}$ and does not exceed the permissible value of $240 \mathrm{MPa}$ (see Table 2).

Likewise, using the presented finite element method, a calculation was carried out for loading cases 2 and 3 (see Table 1), which made it possible to obtain the corresponding stress distribution cloud diagrams (Fig. 4, $b$ and Fig. 4, $c$, respectively). At the same time, it was found that the stress values at the accepted reference point on the upper bollard support (coordinate values: $X=715, Y=0, Z=800$ ) for different loading options are $\sigma_{1}=144.9 \mathrm{MPa}, \sigma_{2}=193.2 \mathrm{MPa}, \sigma_{3}=289.5 \mathrm{MPa}$, thereby determining the relationship between the change in load and stress, which is consistent with the real situation.

\section{The discussion of the results}

To analyze the stresses arising in the elements of the structure, two of its elements were considered, namely, the support of the eyelet 1 and the upper bollard plate 2 (Fig. 5).

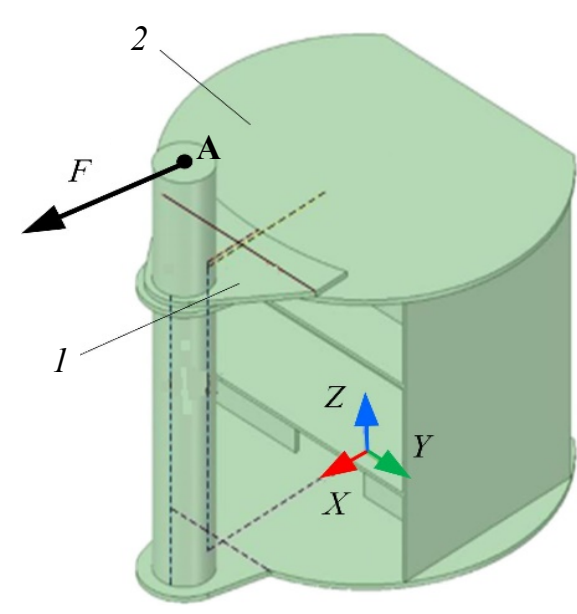

Fig. 5. Numbering of the studied parts of the bollard model

The interest in these structural elements is because they are closest to the point of application of the external load. The values of the arising stresses and their distribution relative to the adopted trajectory (dashed line in Fig. 5) were analyzed under various operating conditions, which were determined by three calculation options.

The graphic interpretation of the results of the calculation of the eye support (structural element 1) was carried out relative to the accepted trajectory and parallel to the $Y$ and $X$ axes (Fig. 6, $a$ and Fig. 6, $b$ ). The calculation results indicate that under different operating conditions, the stress distribution in the element under consideration has obvious symmetry, with an obvious increase in stress along the edges, and the maximum stress value is recorded in the case when $Y$ is determined by values of $-250 \ldots 250 \mathrm{~mm}$ (Fig. 6, $a$ ). As the $X$ coordinate increases (closer to the eyelet), the stress value gradually increases. In the area of the considered element close to the bollard eyelet $(X>550 \mathrm{~mm})$, the change in stress tends to increase significantly (Fig. $6, b$ ). Thus, the changes in stresses in the support of the eyelet near the eyelet itself are more significant than in the rest of the element.

The graphic interpretation of the results of the calculation of the upper bollard plate (structural element 2) is also carried out relative to the accepted trajectory parallel to the $Y$ and $X$ axes (Fig. 6, $c$ and Fig. 6, d). The calculation results indicate that under different operating conditions, like the structural element 2 also has obvious symmetry with an obvious increase in stress along the edges, and the maximum stress value is fixed in the case when $Y$ is determined by the values $-250 \ldots 250 \mathrm{~mm}$ (Fig. 6, c). As the $X$ coordinate increases (closer to the eyelet), the magnitude of the stresses first gradually increases, then decreases, then again gradually increases and, finally, sharply increases. It should be noted that the area of stress reduction as the $X$ coordinate increases in the range of $480 \ldots 555 \mathrm{~mm}$ corresponds to the area of overlap of structural elements 1 and 2 (see Fig. 5), where the stress reduction is associated with a sharp change in the cross section (Fig. 6, $d$ ). In the element under consideration, the nature of the change in stresses near the eyelet itself is also more significant than in the rest of the element. 


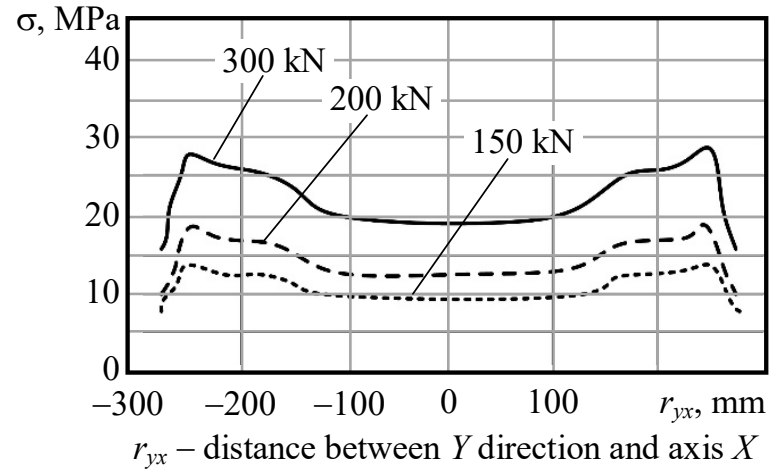

$a$

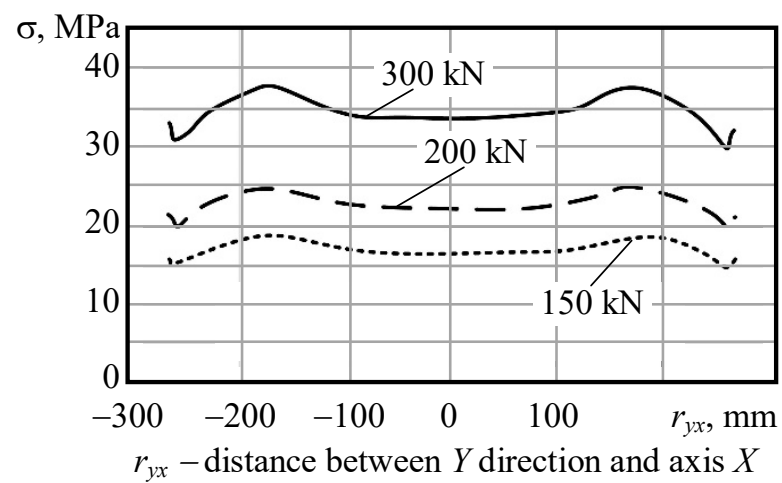

$c$

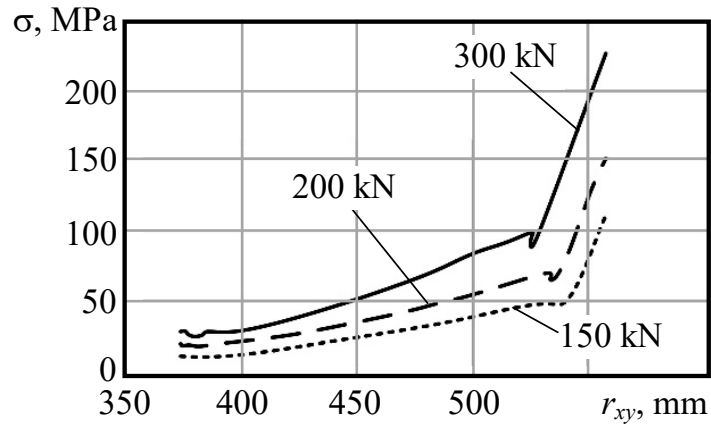

$r_{x y}$ - distance between $X$ direction and axis $Y$

$b$

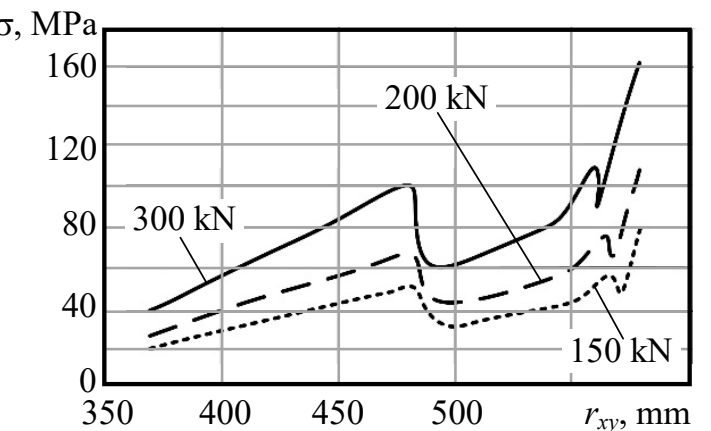

$r_{x y}$-distance between $X$ direction and axis $Y$

$d$

Fig. 6. Distribution of stresses in a structural element 1 and element 2: element 1 parallel to the direction of the $Y$-axis $(a)$; element 1 parallel to the direction of the $X$-axis $(b)$; element 2 parallel to the direction of the $Y$-axis $(c)$; element 2 parallel to the direction of the $X$-axis $(d)$

\section{Conclusion}

Based on the research carried out, the following conclusions were obtained:

1. Comparative analysis of the results of calculating the stress-strain state at the selected reference point, obtained in the case of using the created finite element model of the device in question and its simplified calculation model, indicate their identity with a relative error of $3.6 \%$, which confirms the reliability of the results of the numerical simulation.

2. Based on the obtained law of stress distribution over the elements of the considered floating bollard, the most loaded part of the structure is element 1 at the point of attachment of the eyelet.

3. It was found that on element 1 the greatest stresses arise near the eyelet, at the same time, the stresses in the mating parts of elements 1 and 2 tend to weaken relative to the axis of the eyelet.

4. The data obtained provide a theoretical basis for the installation of warning sensors about the force state of the floating bollard of the ship lock at localized locations.

\section{Література}

1. Felski A., Zwolak K. The Ocean-Going Ships-Challenges and Threats. Journal of Marine Science and Engineering. 2020. № 8. P. 41-50.

2. Иванов В.В. Усилия, действующие на объект швартовки со стороны одиночной якорной связи. Вестник МГТУ: труды Мурман. гос. техн. ун-та. 2011. Т. 14, № 4. С. 724-727.

3. Yang S., Ringsberg J. Towards the assessment of impact of unmanned vessels on maritime transportation safety. Realiability Engineering \& System Safety. 2017. № 165. P. 155-169.

4. Юдин Ю. И. Переменные составляющие воздействия регулярного волнения на корпус судна Вестник МГТУ: труды Мурман. гос. техн. ун-та. 2011. Т. 12, № 3. С. 471-476.

5. Bergdahl L., Palm J., Eskilsson, C., Lindahl, J. Dynamically Scaled Model Experiment of a Mooring Cable. J. Mar. Sci. Eng. 2016. № 4. P. 5-12. 
6. Johanning L., Smith G., Wolfram J. Measurements of static and dynamic mooring line dampingand their importance for floating WEC devices. Ocean Eng. 2007. № 34. P. 1918-1934.

7. Martinelli L., Ruol P., Cortellazzo G. On mooring design of wave energy converters: The Seabreath application. Coast. Eng. Proc. 2012. № 1. P. 3-18.

8. Spanos P.D., Arena F., Richichi A., Malara G. Efficient Dynamic Analysis of a Nonlinear Wave Energy Harvester Model. J. Offshore Mech. Arctic Eng. 2016. № 138. P. 40-49.

9. Tsukrov I., Eroshkin O., Paul W., Celikkol B. Numerical modeling of nonlinear elastic components of mooring systems. IEEE J. Ocean. Eng. 2005. № 30. P. 37-46.

10. Xu Z., Huang S. Numerical investigation of mooring line damping and the drag coefficients of studless chain links. J. Mar. Sci. 2014. № 13. P. 76-84.

11. Chai Y., Varyani K., Barltrop N. Semi-analytical quasi-static formulation for three-dimensional partially grounded mooring system problems. Ocean Eng. 2002. № 29. P. 627-649.

12. Pascoal R., Huang S., Barltrop N., Soares C.G. Equivalent force model for the effect of mooring systems onthe horizontal motions. Appl. Ocean Res. 2005. № 27, P. 165-172.

13. 李荣辉, 吴红霞.长江城陵矶至武汉河段船舶大型化发 展分析. 中国水运, 2010. № 10(6). P. 1-12.

14. Бате К.-Ю. Методы конечных элементов. М. : Физматлит. 2010. 1024 с.

15. Зенкевич О. С. Метод конечных элементов в технике. М. : Мир. 1975. 543 с.

16. Галлагер Р. Метод конечных элементов. Основы. М. : Мир. 1984. 428 с.

\section{References}

1. Felski, A., \& Zwolak, K. (2020). The Ocean-Going Ships-Challenges and Threats. Journal of Marine Science and Engineering, 8, 41-50.

2. Ivanov, V.V. (2011). Efforts acting on the mooring object from the side of a single anchor connection. Vestnik MGTU, 14, 4, 724-727.

3. Yang, S., \& Ringsberg, J. (2017). Towards the assessment of impact of unmanned vessels on maritime transportation safety. Realiability Engineering \& System Safety, 165, 155-169.

4. Yudin, Yu. I. (2011). Variable components of the effect of regular waves on the ship's hull. Vestnik $M G T U, 12,3,471-476$.

5. Bergdahl, L., Palm, J., Eskilsson, C., \& Lindahl, J. (2016). Dynamically Scaled Model Experiment of a Mooring Cable. J. Mar. Sci. Eng., 4, 5-12.

6. Johanning, L., Smith, G., \& Wolfram, J. (2007). Measurements of static and dynamic mooring line dampingand their importance for floating WEC devices. Ocean Eng., 34, 1918-1934.

7. Martinelli, L., Ruol, P., \& Cortellazzo, G. (2012). On mooring design of wave energy converters: The Seabreath application. Coast. Eng. Proc., 1, 3-18.

8. Spanos, P.D., Arena, F., Richichi, A., \& Malara, G. (2016). Efficient Dynamic Analysis of a Nonlinear Wave Energy Harvester Model. J. Offshore Mech. Arctic Eng., 138, 40-49.

9. Tsukrov, I., Eroshkin, O., Paul, W., \& Celikkol, B. (2005). Numerical modeling of nonlinear elastic components of mooring systems. IEEE J. Ocean. Eng., 30, 37-46.

10. Xu, Z., \& Huang, S. (2014). Numerical investigation of mooring line damping and the drag coefficients of studless chain links. J. Mar. Sci., 13, 76-84.

11. Chai, Y., Varyani, K., \& Barltrop, N. (2002). Semi-analytical quasi-static formulation for threedimensional partially grounded mooring system problems. Ocean Eng., 29, 627-649.

12. Pascoal, R., Huang, S., Barltrop, N., \& Soares, C.G. (2005). Equivalent force model for the effect of mooring systems onthe horizontal motions. Appl. Ocean Res., 27, 165-172.

13. Li Ronghui, \& Wu Hongxia. (2010). Analysis on the development of large-scale ships in the Yangtze River from Chenglingji to Wuhan. China Water Transport, 10(6), 1-12.

14. Bate, K.-Yu. (2010). Finite element methods. Moscow: Fizmatlit.

15. Zenkevich, O. S. (1975). Method of finite elements in technology. Moscow: Mir.

16. Gallager, R. (1984). Method of finite elements. Basics. Moscow: Mir.

Чжан Юн; Zhang Yong, ORCID: https://orcid.org/0000-0001-9347-2071

Сидоренко Iгор Іванович; Sydorenko Ihor, ORCID: https://orcid.org/0000-0003-1840-4313

Прокопович Iгор Валентинович; Prokopovych Ihor, ORCID: https://orcid.org/0000-0002-8059-6507

Чжан Юнсюань; Zhang Yunxuan, ORCID: https://orcid.org/0000-0001-9384-5042

Вороненко Сергій Вікторович; Voronenko Serhii; ORCID: https://orcid.org/0000-0001-9606-6538

Received March 18, 2021

Accepted May 06, 2021 